\title{
Intersections of nationality, gender, race and crime in news reporting: the case of Oscar Pistorius - Olympian and murderer
}

Article

Accepted Version

Creative Commons: Attribution-Noncommercial-No Derivative Works 4.0

Hunt, S. and Jaworska, S. (2019) Intersections of nationality, gender, race and crime in news reporting: the case of Oscar Pistorius - Olympian and murderer. Discourse, Context \& Media, 30. 100299. ISSN 2211-6958 doi:

https://doi.org/10.1016/j.dcm.2019.100299 Available at https://centaur.reading.ac.uk/83510/

It is advisable to refer to the publisher's version if you intend to cite from the work. See Guidance on citing.

To link to this article DOI: http://dx.doi.org/10.1016/j.dcm.2019.100299

Publisher: Elsevier

All outputs in CentAUR are protected by Intellectual Property Rights law, including copyright law. Copyright and IPR is retained by the creators or other copyright holders. Terms and conditions for use of this material are defined in the End User Agreement.

www.reading.ac.uk/centaur 
Central Archive at the University of Reading

Reading's research outputs online 
Intersections of nationality, gender, race and crime in news reporting: The case of Oscar Pistorius - Olympian and murderer

Keywords: intersectionality; sport reporting; UK media; South African media; corpus linguistics; Oscar Pistorius; gender; race; disability

\section{Abstract}

Taking as the starting point the importance of adopting an intersectional approach to studying mediatised representations, this study focuses on media construals of the South African athlete Oscar Pistorius. Spanning a range of intersecting identities - he is white, male, disabled, a sports champion and a convicted murderer - Pistorius presents an important case to study. In this paper, we focus on the period from his success in the 2012 London Olympics to his 'fall from grace' after fatally shooting his girlfriend in 2013. We use a combination of corpus linguistic tools and methods, and Critical Discourse Analysis, to interrogate corpora of press articles published in major British and South African newspapers. Investigating collocational patterns surrounding Pistorius, we show how media 'mix and match' aspects of his identity to construct a particular kind of persona. Whereas his disability and (trans)national identity are foregrounded in constructing him as a sports hero, his new emotionality and mental vulnerability are emphasized through gendered representations in the UK while a largely individual representation dominates in South Africa, where he is referred to overwhelmingly by name and in terms of his crime as an amputee, and only obliquely as white and male. At the theoretical level, our study adds to the body of research which challenges the notion that individual experience can be understood by categorising people in terms of one identity component (gender, race, ethnicity). More importantly, it shows that different 
aspects of identities are foregrounded or backgrounded to navigate shifts in salience in sometimes conflicting identity/ies, and that this is accomplished differently in two different media traditions. At the methodological level, this study shows the potential of a diachronic collocational analysis to unravel patterns of intersectionality in mediatised identity constructions.

1. Introduction: Intersectionality, mediatisation and hegemonic identities

Taking as the starting point the importance of adopting an intersectional approach to studying mediatised representations, this study focuses on media construals of the South African athlete Oscar Pistorius. Spanning a range of intersecting identities - he is white, male, disabled, a sports champion and a convicted murderer - Pistorius presents an important case to study.

Oscar Pistorius, born in South Africa in 1986, is an accomplished athlete despite having had both lower limbs amputated below the knee as an infant, due to birth defects. In 2012 he became the first amputee runner to compete in the Olympic Games alongside able-bodied athletes. In the early hours of 14 February 2013 he shot and killed his girlfriend, Reeva Steenkamp, in their Pretoria home in a secure complex. He claimed to have mistaken her for an intruder when he fired shots through the bathroom door. The trial attracted national and international interest, and was broadcast live daily on South African television. He was initially found guilty of culpable homicide, a verdict which was subsequently overturned and changed to murder. The original sentence of 5 years in jail was eventually increased to 15 years, less time served, on appeal by the state. 
Given that intersectionality has been mostly used to explore disadvantaged and marginalised social actors, the question arises as to why we should look at a villain who exhibits features of hegemonic masculinity? Oscar Pistorius presents an interesting blend of advantage and disadvantage: young and athletic in a world which values both highly, white and male in socially stratified South Africa, but physically disabled and convicted of murder. How these competing elements of his identity are selected in his representations in the media and what kind of ideological work this mixing and matching may perform in maintaining hegemonic identities is the main subject of this paper.

The notion of intersectionality is now an established theoretical and analytical tool in sociology offering profound insights into the ways in which multiple dimensions of established social categories such as race, gender, class or age interact to form identities and 'structure' personal lived personal experience. Born out of the feminist critique of excluding African-American women from anti-discrimination law (Crenshaw, 1991), intersectionality challenges the notion that individual experience can be understood by categorising people into binary social groups, for example, just as women or men, black or white, gay or straight. Each individual is a member of different social groups and this multiple membership determines individual's positioning on a social continuum and is largely responsible for access to resources, privileges or lack of thereof. Intersectionality has raised the awareness of the diversity within each social category showing how social categories overlap and at times are intimately tied together. It has proved to be productive in revealing the underlying mechanics of marginalisation and oppression demonstrating how certain aspects of multiple social memberships can be foregrounded or 
backgrounded in a particular context or in a particular point of time and result in multifarious disadvantage or privilege.

Although the notion of intersectionality has to date been rarely spelt out in linguistic research (Jaworska and Hunt, 2017; Levon, 2015; Milani, 2015), the principle of interacting social categories is not new. Since the late 1980s, research in variationist sociolinguistics has largely departed from the notion of stable correlations between a social category such as age or gender and linguistic practices. Studies conducted in the course of the second and third wave of sociolinguistic research have shown (Eckert, 2016) that linguistic practices emerge locally at the intersection of one or more variables and change as the individual moves from one social context to another (e.g. Eckert, 1989; Bucholtz, 2011; Levon, 2014). This research has also shown the interlocking dimension of 'othering' in that it is almost always a combination of social and linguistic factors that lead to the formation of stereotypic views about social groups. These are often readily taken up in public imagination and become 'naturalised' or taken for granted attributes. In this way, most representations are composed of social and semiotic 'layers' forming intersectional sublimates of dominant ideologies.

In this paper, we argue that media and specifically the process of mediatisation (Jaffe, 2011) act as important vehicles of producing and reproducing such ideological deposits by selectively choosing and foregrounding a particular set of social, linguistic and other semiotic aspects of identity to represent a social actor as a particular kind of persona for certain performative and ideological purposes, for example to fit certain stereotypical and popular views and attract readership (see also Jaworska and Hunt, 2017; Milani, 2015). Examining 'representational choices' made to depict social actors (Jaffe, 2011: 98) from 
the point of view of intersectionality can help unpack the complex layers of interactions between social and semiotic characteristics and show how they are purposefully 'mixed and matched' to perpetuate and legitimise hegemonic identities and practices.

Our understanding of hegemonic identities follows from Kiesling's (2006) conceptualisation which defines it as a dominant position based on a shared cultural model comprised of different social categories. This shared cultural model is nothing more than a set of Discourses that construct and reinforce, through small d discourses or in other words language in use, ways of thinking and perceiving social categories (Gee 2014).

This has two important implications for the understanding of the hegemonic identity of masculinity, which underpins this study: first, the hegemonic identity of masculinity is not a monolithic construct based only on the dominant norms and practices related to being a man but a constellation comprising different social categories, most notably race and sexuality. Secondly, hegemonic identity is not a given, to be 'put on' when required. Rather, it is a repertoire of social categories which, as with any other form of identity, results from 'discursive work' (Zimmerman and Wieder 1970). The discursive work mobilised to convey identities is not a universal framework but a set of resources that differ from context to context and from social occasion to social occasion. Exploring the discursive work, or instances of language use, employed to convey hegemonic identities in different contexts can help us understand better the mechanics underlying the constructions and disseminations of hegemonic identities and practices. This is important because hegemonic identities are maintained not through coercion but rather through subtle means of control and consent. Mainstream media as institutions of power, and 
language used in the media reflecting representational choices (Johnson and Ensslin 2007), play a crucial role in sustaining hegemonic identities and practices.

It is important to bear in mind that hegemonic identities, although pretty sedimented, are never completely set in stone and open to appropriation. Kiesling (2010:262) notes that an important aspect of hegemonic identity is "its ability to change in the face of challenge" though the contesting discourse often ends up being used as a legitimation tool to sustain the hegemony, albeit in a slightly different format. To better understand the mechanics of hegemony in society, it is therefore imperative to explore the social and semiotic layers that constitute hegemonic identities and how these 'behave' in moments in which these identities become open to contestations.

We propose to address these complex intersections by examining media representations of Oscar Pistorius - a sport hero turned murderer. We endeavour to do so by exploring the discursive work, specifically lexical choices, mobilised in the media to depict Pistorius during the Olympics in 2012 when he participated in the able-bodied Olympics, and during his murder trial in 2013. In order to identify the lexical choices, we adopt a corpus-based approach and its analytical tool of collocation. Collocations understood as recurrent word combinations are not just a matter of individual preference but reflect established, and often taken for granted, discursive practices of the communities in which they were produced (Stubbs 2001). Collocations are therefore useful for this study as they could point to the existence of discursive patterns that are indicative of hegemonic identity constructions in the media (cf. Baker 2006).

We have chosen to compare representational choices used to depict Pistorius in the media of his home context (South Africa) and outside this context in the UK, for a 
number of reasons. Firstly, we analyse data from two contexts in order to account for the contextual nature of identity constructions and to avoid the pitfalls of a unicultural discourse analysis which might lead to unwarranted overgeneralization (Chilton 2011, Leuschner and Jaworska 2018),

Secondly, and more specifically, comparisons assist researchers in identifying the salient features of a corpus: significant patterns or collocations within an individual corpus are more easily found if it is compared with another corpus, thus acting in a similar way to a reference corpus. Comparison may therefore go beyond simple description and reveal which particular aspects of composite identity may be emphasised in one context and glossed over in another, suggesting differing levels of salience in each.

Thirdly, in the context of an intersectional analysis, we are interested in the representation of Pistorius in terms of his nationality, with a comparison between coverage in the country where he lives and one where he does not, offering the potential to illuminate this aspect of his identity in the two time periods. Similarly, with race, contrasting reportage in a country with a history of legalised, systemic racism, and one where it is less overt, is the ideal way to tease out this particular aspect of identity.

The choice of contrasting the representations found in South Africa with those in the UK in particular, rests on the fact that Pistorius lives in the former, and was representing Team SA, at an international event in the UK, increasing the likelihood of reports on his Olympic performance in both contexts during the first period of data collection. In addition, the London Olympics and the murder occurred less than one year apart, and the coverage of the trial in the UK reflects that he was still regarded as a newsworthy figure 
there, thus making UK media attention an appropriate comparison to the South African reporting.

Since our research crosses and combines linguistic research in two areas, to our knowledge for the first time, that is, representations in the media of sport and of crime, Section 2 provides a short overview of major trends identified in research exploring representations of athletes and crime. Subsequently in Section 3, we outline our methodology and the data, whereas Section 4 discusses the main findings. We conclude our paper with observations regarding intersectionality in representational choices in movements of contestations and how these choices sustain hegemonic identities albeit in slightly modified ways. We also discuss the impact of the cultural and socio-political context on representational choices and the kind of intersections that are foregrounded or backgrounded. We finish with a summary of the benefits of a diachronic collocation analysis to reveal patterns of intersectionality in representational choices in the media.

\section{Crime and Sport in the Media}

Media play an important role in representing crime for the public: most people who are not involved in crime or have not witnessed a criminal act only become aware of criminal activities through media reports. This necessitates the scrutiny of the representations of crime in the media, given the centrality of the media in defining what the public need to know about crime and constructing, and, therefore, 'much of the reality of crime and justice' (Surette, 2009: 239). Given that there is a 'voracious public appetite for crime news' (Jewkes, 2004: vii), crime stories have a high level of newsworthiness, 
though not all crimes are equally newsworthy. What makes a crime event worth reporting depends on the type of crime and the social background of the victims, which in turn is filtered through a predominantly Western, white, heteronormative, middle-class and male lens (Henry and Tator, 2006). For example, sexual crimes top the list of crimes reported in the media but not all sexual crimes receive the same level of attention (Harper and Hougue, 2015). The sexually driven homicides of white, attractive, heterosexual females from respectable households receive much more attention than any other type of crime and are often underpinned by sensationalist representations (Jewkes, 2004), while domestic violence and sexual crimes against non-white and poor women often go unreported. If they are reported, the victims are often represented as somehow 'deserving' of their fate (Gilchrist, 2010), while white victims are presented as innocent, defenceless and vulnerable (Farr, 2001) and valued members of society (Tabbert, 2013).

Representations of victims contrast sharply with those of perpetrators who tend to be depicted as deviant, a 'breed apart' (Kitzinger, 2009: 87) or 'cold calculators' (Farr, 2001). There is a general tendency to sensationalise and demonise offenders (Machin and Mayr, 2013), which in turn can lead to 'media-made pre-trial conceptualisations' (Statham, 2016: ix) and a trial in the court of public opinion. Such pre-trial conceptualisations can be detected in the linguistic choices made in the media. For example, Tabbert (2013) has shown that perpetrators are often labelled as such before conviction (in phrases like 'the alleged killer') and represented using metaphors likening them to animals (Machin and Mayr, 2013).

Media foreground race too in that people black people tend to be overrepresented as lawbreakers and offenders, and white people as victims. This does not correspond to what 
actually happens in reality: according to crime statistics in the UK and US, members of non-white communities are more likely to be victims of violent crime than white people (Webster, 2017), and, in South Africa, black males are proportionally more likely to be murdered than white males (Umraw 2018), although crime statistics there are not reported in terms of race. Such overrepresentations lead to a distorted and prejudiced view of crime such that in the public imagination a typical violent offender is associated with being non-white, mostly of an African background (Dixon, 2005). In addition, there is a tendency to portray crimes committed by white people as individual crimes, often due to mental illness, whereas crimes committed by non-white people are attributed to problems connected to their social identity and the community in which they live, with the communities being often pathologized and seen as broken and separate from mainstream (white) society (Gilliam et al., 1996; Dixon, 2017).

The murder committed by Pistorius fits the dominant media representations of crime and is newsworthy in that the victim is a white, young, attractive, middle-class woman. It is, at the same time, unusual in that the perpetrator is a celebrated, white, Olympic hero and heroes are not normally murderers. The case warrants scrutiny, as it opens up a space for representational tensions and contestations at the intersections of crime, sport and race.

Representations of sport in the media, specifically comparisons of sportsmen with sportswomen have received a great deal of attention in media studies and sociology and it is beyond the scope of this paper to offer a full overview of this large body of research (for useful summaries see Messner et al., 1993; Bruce et al., 2010; Jaworska and Hunt, 2017). For the purpose of this paper and specifically its focus on hegemonic identities 
and intersectionality, it is important to keep in mind that sport itself is an intersectional terrain per se (Bruce et al., 2010). The hegemonic identity which the media across the world foreground is that of a white, young, heterosexual, able-bodied, middle- or upperclass and nationally (even internationally) successful male athlete. Identities that 'deviate' in some way from this ideal are scrutinized, judged, problematized and often misrepresented. This concerns especially athletes who are non-white and female. Paying close attention to linguistic choices used to construct media representations of sportsmen and sportswomen, Jaworska and Hunt (2017) show how in the context of global sports events, gender, nationality and sporting success intersect to form a gender-neutral identity for successful sportswomen, but only for gold medallists. However, as exemplified in the case of the British distance runner Mo Farrah, race can become a marker of 'othering' for non-white gold medallists.

Against this background, Oscar Pistorius represents in many ways the hegemonic ideal sportsman. What is interesting, however, is the dramatic shift of identity following the murder of his girlfriend, which turns him into a killer and opens up the possibility of the contestation of the hegemonic sporting identity. What kinds of representational choices are made to construct this shift for the public? To what extent is the hegemonic identity of a white, young, middle-class and successful athlete maintained, or possibly contested, through these choices? These are the main questions which this paper attempts to address.

\section{Methodology and Data}

Our research falls into the broad area of corpus-assisted or corpus-based discourse 
analysis, which is increasingly used to examine identity representations across media (e.g. Jaworska and Krishnamurthy, 2012; Baker et al., 2013; Hunt 2015) and, more recently, to explore the representation of sport and/or athletes, such as work by Aull and Brown (2013), Caple (2013), Jaworska (2016) and Jaworska and Hunt (2017). CADS utilises the quantitative tools of Corpus Linguistics to identify patterns of ideological interest in large bodies of language data. The analysis of frequencies and collocations reveals often covert trends in print media reporting and these have ideological significance in terms of the ways in which the world is represented. High frequencies for particular lemmas show the central preoccupations of the texts in the corpus: for example, the dominant ways of referring to people, while absences or low frequencies can indicate concepts and views which are backgrounded or ignored. Collocation, a measure of how frequently word forms co-occur with each other, as opposed to separately, in the corpus, can reflect which concepts are frequently associated with each other, and suggest how they are coloured by the association.

In this project our focus is on Oscar Pistorius, both during the Olympics in 2012 when he participated in the able-bodied Olympics, and during the murder trial following the death of his girlfriend, Reeva Steenkamp, on Valentine's Day in 2013. We are concerned with which elements of his identity, including gender, disability, race and nationality, are foregrounded, and which backgrounded, in the two time periods under investigation. Building on this, we consider how media representations in the UK and in South Africa deal with the contrast between his initial status as a successful Olympic athlete, and his later identity as a murder-accused. Our research questions are therefore the following:

i. What are the differences and similarities between his representation in 2012 and in 
2013/2014 in the print media of the UK and of South Africa?

ii. How are various aspects of his identity (nationality, race, gender, age, his role as an international athlete, and his status as disabled person) foregrounded, backgrounded and juxtaposed across time and across the two different cultural and socio-political contexts?

iii. How do the media juggle representing one man, who is both a hero and a murderer?

To answer these questions, we built four sub-corpora of reports from prominent print media sources in the two countries. In each case, we selected articles reporting on Oscar Pistorius using Oscar and Pistorius as search terms. Using Newsbank for South Africa and Nexis for the UK, we searched for and saved all relevant articles in the selected time periods, in UTF-8 format for use in Sketch Engine (Kilgarriff et al., 2014). We chose Sketch Engine as it offers such useful facilities as word sketches, which compute the behaviour of search terms in the given corpus in terms of grammatical roles and collocates within identified syntactic structures. However in this paper our focus is on the patterns we found in terms of frequency and collocation, as described above.

Table 1: Corpora and their sizes

\begin{tabular}{|c|c|c|c|c|c|}
\hline Time period & Dates & $\begin{array}{l}\text { Corpus } \\
\text { Name }\end{array}$ & Sources & Articles & Words \\
\hline \multirow[t]{2}{*}{$\begin{array}{l}\text { London } \\
\text { Olympics }\end{array}$} & $\begin{array}{l}27 \text { July } \\
2012 \\
\text { to } \\
12 \text { August }\end{array}$ & UK1 & $\begin{array}{l}\text { Daily Mail, Daily } \\
\text { Telegraph, } \\
\text { Guardian, } \\
\text { Mirror, Observer, } \\
\text { Sun, Sunday } \\
\text { Times, The Times }\end{array}$ & 115 & 66,281 \\
\hline & $\begin{array}{l}12 \text { August } \\
2012\end{array}$ & SA1 & $\begin{array}{l}\text { The Times, The } \\
\text { Sunday Times }\end{array}$ & 17 & 9,831 \\
\hline
\end{tabular}




\begin{tabular}{|c|c|c|c|c|c|}
\hline \multirow[t]{2}{*}{$\begin{array}{l}\text { Murder to } \\
\text { conviction }\end{array}$} & \multirow[t]{2}{*}{$\begin{array}{l}\text { 14 February } \\
2013 \\
\text { to } \\
28 \text { October } \\
2014\end{array}$} & UK2 & $\begin{array}{l}\text { Daily Mail, Daily } \\
\text { Telegraph, } \\
\text { Guardian, } \\
\text { Mirror, Observer, } \\
\text { Sun, Sunday } \\
\text { Times, The Times }\end{array}$ & 1,008 & 350,161 \\
\hline & & SA2 & $\begin{array}{l}\text { Daily Sun; The } \\
\text { Star; The Times, } \\
\text { The Sunday Times }\end{array}$ & 1,342 & 648,874 \\
\hline
\end{tabular}

As the trial spans a far longer time period than the London Olympics, the second corpus in each context is much larger than the first, both in terms of articles collected and total running words (see Table 1). Early data from the (South African) Daily Sun was not available at the time of collection. The UK data total 416,442 words while the SA subcorpora comprise 658,705 words, resulting in a corpus of over a million words altogether $(1,075,147)$. The South African corpus represents more than half of the data, at just over $61 \%$ of the total, which is not surprising given Pistorius's interest to local readers as a fallen hero. Although the amount of data collected during the trial was predictably much greater in South Africa, reporting there on the Olympics was far less than the coverage in the UK, resulting in the SA1 sub-corpus being much smaller than the others. This was exacerbated by the absence of Daily Sun data for that period. While we would have preferred less of a disparity between the sizes of the sub-corpora, the differences did not deter us unduly from our aim, which was to identify patterns of ideological significance in the representations of Oscar Pistorius, and SA1, although smaller, was useful in showing up differences of this kind between the time periods.

As our main focus is on the aspects of Oscar Pistorius's identity that are foregrounded and those that are ignored or backgrounded, we used Sketch Engine to generate lists of collocations of Pistorius, the most frequent of the expressions used to refer to him, as 
recurrent associations can highlight aspects of identity and attributions that are foregrounded. Using the Mutual Information (MI) score as the measure of association, we specified a span of $5 \mathrm{~L}$ to $5 \mathrm{R}$, meaning that the search for collocates was limited to 5 words on either side of the search term Pistorius. This recognises that words which are further apart than this are unlikely to affect each other as much as those which fall within this window. Scores over 3.84 are considered to be statistically significant, in other words the patterns they indicate are unlikely to have occurred by chance. We also set 3 as the minimum frequency for candidate collocates, as single instances of collocation do not typically suggest strong patterns of representation. Focussing on lemmas, headwords for related word forms, such as $\mathrm{GO}=$ go, goes, went, we extracted the content words (nouns, verbs, adjectives and adverbs) from the collocations and grouped these manually into semantic categories by consulting the use of each word in its linguistic context. Comparing the results for the four sub-corpora revealed sharp differences between the data sets and suggested interesting shifts in how the same person may be represented in media texts across contexts.

\section{Results}

4.1 Representations of Pistorius in the London Olympics corpora

As Table 2 shows, most of the collocations of Pistorius refer to his achievement in the London Olympics celebrating him as a person breaking barriers and a global star. This is evidenced in the use of collocations such as dream, history, achievement, amazing and remarkable. The frequent references to history (18 times) in the vicinity of Pistorius emphasise, in particular, his significance and exceptionality as sportsperson. 
Table 2: Collocations of Pistorius in UK1 (grouped into semantic categories)

\begin{tabular}{|l|l|l|}
\hline Semantic category & Collocation & Total Freq. \\
\hline Naming of Pistorius & $\begin{array}{l}\text { Oscar (116), (blade) runner (24), athlete (10), } \\
\text { champion (5) }\end{array}$ & 155 \\
\hline Achievement & $\begin{array}{l}\text { dream (19), history (18), semi-final (17), 400m } \\
\text { (17), Olympic (12), second (11), heat (10), } \\
\text { Olympics (7), experience (6), final (6), achieve } \\
\text { (5), achievement (3), championship (3) }\end{array}$ & 134 \\
\hline National identity & Africa (19), South (30), African (17) & 63 \\
\hline Actions & $\begin{array}{l}\text { say (22), run (17), swap (11), become (6), compete } \\
\text { (5), embrace (4) }\end{array}$ & 65 \\
\hline Disability & $\begin{array}{l}\text { (double) })^{1} \text { amputee (16), (no) legs (10), amputate } \\
\text { (6), disabled (3) }\end{array}$ & 35 \\
\hline Evaluation & last (14), amazing (4), remarkable (3), unique (3) & 24 \\
\hline Other social actors & Kirani (5), Usain (5) & 10 \\
\hline Other & $\begin{array}{l}\text { name (badge) (12), end (8), time (7), team (7), } \\
\text { yesterday (6), sport (5), emotions (3), }\end{array}$ & 48 \\
\hline & & \\
\hline
\end{tabular}

Extracts 1 and 2 are indicative examples of the discourse around the historical importance of his achievement:

1) BLADE runner Oscar Pistorius made history yesterday when he became the first double amputee to run in the Olympics. (Mirror)

2) It is an overused phrase but there was one man here who could lay claim genuinely to making history. Oscar Pistorius, the Blade Runner .... (Observer)

There are some references to his disability but these are used mostly to emphasise his exceptionality as a person who was able to overcome the incapacity, compete with 'ablebodied' athletes and break down barriers (see Extracts 3 and 4).

\footnotetext{
${ }^{1}$ The word in brackets, in each case, is the most frequent word that patterns with the collocate of the search term. The inclusion of the most frequent and significant of these words is often useful to show how particular phrases can become fixed expressions, collocates of the strongest kind, which provide preformed chunks of representation. These additional words are also useful to clarify the meaning of collocates in context e.g. legs, in this corpus, does not refer to these body parts as such, but to the absence of legs, as in 'no legs'.
} 
3) Pistorius, known as the Blade Runner for his carbon-fibre prosthetic legs that are fitted below the knee, is a global star these days. (Daily Mail)

4) Pistorius secured his place in sporting history by becoming the first double amputee to compete at the Olympics. (Telegraph)

That he is celebrated on a par with other 'able-bodied' sportsmen is evident in the use of two other collocates Kirani and Usain in the vicinity of Pistorius. Interestingly, names of other Paralympians do not occur together with Pistorius. Overall, the collocational profile of Pistorius in the UK Olympics Corpus shows a classic representation of a sports hero, which draws on interlinked categories of remarkable achievement, physical ability, positive evaluation and to some extent nationality.

Table 3: Collocations of Pistorius in SA1 (grouped into semantic categories)

\begin{tabular}{|l|l|l|}
\hline Semantic Domain & Collocations & Total Frequency \\
\hline Naming of Pistorius & Oscar (30) & 59 \\
\hline Achievement & $\begin{array}{l}\text { history (4), yesterday } \\
\text { (4), olympic (3) }\end{array}$ & 11 \\
\hline National identity & $\begin{array}{l}\text { South (5), Africa (3), } \\
\text { team (3) }\end{array}$ & 11 \\
\hline Actions & $\begin{array}{l}\text { say (4), make (4), take } \\
(3)\end{array}$ & 11 \\
\hline Disability & - & 0 \\
\hline
\end{tabular}

Table 3 shows the most frequent collocates found in the vicinity of Pistorius in the Olympics corpus of SA news (SA1). There is a considerably smaller number of collocations in this data set due to a relatively smaller size of the corpus. Here too, media reports centre around the achievements of Oscar in the Olympics, rather than the Paralympics, who was competing against 'able-bodied' athletes. However, instead of focussing on his disability, reports emphasize his nationality and the historically singular 
nature of his participation: as can be seen with the collocates under Achievement and National Identity. Stressing the achievements of local athletes such as Oscar Pistorius in Team South Africa is central to the media coverage in the home country, in the same way that the nationality of the athletes in Team GB was important in UK reporting on the London Olympics (Jaworska and Hunt, 2015). Apart from his name and nationality, Oscar is also referred to in this corpus by a range of epithets, which together build a picture of his exceptionality in terms of his extraordinary ability in the context of his disability, having had both legs amputated. He is referred to in the following ways: (1) the fastest man on no legs, (2) Paralympic legend, (3) takes to the track with blades, (4) the first double amputee to compete at a Games, (5) blade runner, (6) disabled athlete and (7) made Olympic history yesterday. Several of these are plays on words or make reference to existing expressions and so link to them intertextually, such as (1), which is a slight, but unexpected, adaptation of the phrase 'the fastest $\mathrm{X}$ on two legs' and emphasizes the surprising nature of his success, and (5) which refers to the film of that name. Pistorius is specifically invoked as an example of success against the odds, as an inspiration of what could be achieved by fellow South Africans, and, in fact, by the country as a whole.

5) Let's not forget the sheer brilliance of Oscar Pistorius. .... By punching above his weight, he stands as an enduring symbol of will power, fortitude and grace. (Sunday Times) 
6) Like Pistorius, we can beat the odds. South Africans face many adversities.

But the Blade Runner shows they can be overcome.... His life could spark people to reach beyond the boundaries (Sunday Times)

What is striking, in the context of SA, is that despite these glowing descriptions of his symbolic value for the country, he is not once referred to as a hero in SA1.

\subsection{Representations of Pistorius in the Murder to Conviction Corpora}

On 14 February 2013, Oscar Pistorius hit the headlines again; this time not as a sports hero but as the killer of his girlfriend Reeva Steenkamp. This marks a dramatic shift in his life and identity to which the media were not indifferent. How did they respond to this shift and what kind of representational choices were made to manage this apparently irreconcilable identity transition?

Table 4: Collocations of Pistorius in UK2

\begin{tabular}{|l|l|l|}
\hline Semantic Domain & Collocations & $\begin{array}{l}\text { Total } \\
\text { Frequency }\end{array}$ \\
\hline Naming of Pistorius & $\begin{array}{l}\text { Oscar (722), Mr (302), (blade) runner (34), } \\
\text { athlete (24), suspect (24), boyfriend (14), killer } \\
\text { (13), sprinter (12), Paralympian (11) }\end{array}$ & 1,156 \\
\hline $\begin{array}{l}\text { Bodily and mental } \\
\text { states and actions }\end{array}$ & $\begin{array}{l}\text { weep (44), break (down) (23), sob (21), suicide } \\
\text { (19), vomit (17), suffer (15), cry (12), } \\
\text { composure (11), shake (9), jealous (8), tearful } \\
\text { (8), traumatise (7), bow (6), horrify (5), howl } \\
\text { (5), heartbroken (5), collapse (5), crack (5), } \\
\text { composure (5), verge (of suicide) (5), wail (5) }\end{array}$ & 233 \\
\hline Court procedures & $\begin{array}{l}\text { deny (87), accuse (56), charge (16), admit (13), } \\
\text { appear (12), affidavit (12), plead (11), barrister } \\
\text { (11), compensation (3), prosecutor (3) }\end{array}$ & 224 \\
\hline Other actions & shoot (60), fire (49), killed (6), resuscitate (4) & 119 \\
\hline Social relations & uncle (17), ex-girlfriend (16), aunt (6), & 42 \\
\hline
\end{tabular}




\begin{tabular}{|l|l|l|}
\hline & housekeeper (3) & \\
\hline Evaluation & psychiatric (16), red-eyed (3) & 19 \\
\hline Disability & (double) amputee (14), amputation (5) & 19 \\
\hline Other & $\begin{array}{l}\text { say (15), negligent (10), undergo (9), suit (7), } \\
\text { bucket (6), hinge (3) }\end{array}$ & 50 \\
\hline
\end{tabular}

Collocations of Pistorius in UK2 (see Table 4) point to a representational option based on the emphasis of bodily and mental actions and states of the accused. There is a heavy focus on emotional leakage as evidenced by the frequent and strong associations of Pistorius with verbs and adverbs of crying including weep, sob, cry, wail, howl and tearful with weep and sob being the most frequent. Moreover, the verbs do not just occur in the vicinity of Pistorius; in most cases it is Pistorius who is the subject of the action of crying. For example, out of the 41 instances of weep, 31 have Pistorius as the subject. Similarly, 17 instances of $s o b$ in the vicinity of Pistorius point to the athlete as the 'performer' of sobbing. In case of cry, wail and howl all instances have Pistorius as the subject.

According to the British National Corpus (BNC), which acts as a representative corpus of British English and is often used by corpus linguists to check patterns of general lexical associations in this variety of English, the most frequent grammatical subjects of weep and sob are women and small children. This suggests that Pistorius is imbued here with characteristics typically associated with innocent and less powerful groups, which adds a gendered perspective to his representation in the UK corpus. This projected vulnerability is further intensified by other frequent bodily associations including verbs and nouns such as vomit, break down, collapse, suicide and shake (all with the MI score greater than 5). Extracts $7-10$ are illustrative of the description of Pistorius' emotional dissolution which dominates the corpus: 
7) Pistorius broke down and vomited as his murder trial heard details of a postmortem carried out on the body of his lover Reeva Steenkamp, 29, who was gunned down. (Mirror)

8) Gruesome images of the model Reeva Steenkamp shortly after her death were inadvertently shown to a packed courtroom yesterday, causing Oscar Pistorius to vomit. (Guardian)

9) Pistorius's whole body shook and he wept uncontrollably, as if a chasm of grief threatened to swallow him. (Observer)

10) Weeping athlete Pistorius, 27, bowed his head before vomiting as a pathologist revealed the details of the model's post-mortem. (Daily Mail)

Such depictions are not normally used to portray offenders, who, as research has shown, tend to be demonized. The focus on his emotional collapse, associated with stereotypically female behaviour, childish innocence and weakness, could potentially mobilize some sympathy for the accused amongst the readers. The frequent mentions of suicide in the vicinity of Pistorius signal his mental instability and the possibility of selfharm. Such representations depart from the hegemonic identity of masculinity, which is normally based on the notion of toughness and emotional detachment (boys don't cry), but, we would argue, could evoke feelings of sympathy for the accused.

Although media have been shown to often 'pre-trial' offenders (Statham 2016: ix) by labelling them as criminals before conviction, this is not the case in the reporting of Pistorius in the UK. In UK2, we do not find direct references to Pistorius as a murderer and the words murderer and murder do not collocate with Pistorius in this corpus. He is described as a killer 17 times but only relatively late in the reporting, in the month in 
which he was convicted of his crime. Before then he was referred to merely as a suspect (24). His status as a sporting hero, indicated by frequent references to his sporting abilities (athlete, blade runner), and as a wealthy celebrity who could potentially sue the newspapers might have reduced the media tendency for pre-trialling. Although further research is needed to corroborate this, it may be that media abstain from pre-trialling in cases of wealthy and well-known individuals because they could potentially threaten the media industry with costly lawsuits. Offenders who do not have the same status and resources might be more likely to be pre-trailed because they pose less of a threat.

Overall, there seems to be a focus on his new emotionality and mental vulnerability, blurring the usual media binary of perpetrator-victim and marking a representational reversal from hero to 'victim'. This becomes evident in the use of three strong verbal collocates: suffer, horrify, traumatise. Arguably, traumatise implies physical or mental injury which is caused by external factors or events and not one's own actions. The top 3 collocations of traumatise in the BNC are events, experience and children and the verb is normally used to emphasise negative consequences for innocent and vulnerable victims such as children. Out of the 7 instances of the lemma traumatise in the vicinity of Pistorius, 5 have Pistorius as the subject who was traumatised. Suffer is used similarly; the top collocates in the BNC are injury, loss, damage and attack. In UK2, suffer collocates with Pistorius 15 times and in all instances, he is the suffering subject. Extracts $11-14$ are indicative of the reversal pattern presenting him as a victim rather than an offender: 
11) The surprising move came after defence witness and forensic psychiatrist Dr Merryll Vorster said Pistorius suffered from generalised anxiety disorder at the time of the shooting, and a depressive disorder following it. (The Guardian)

12) Oscar Pistorius suffered an emotional collapse on the witness stand and let out great, heaving sobs as he relived "the moment that everything changed" (Mirror)

13) The report by Weskoppies [psychiatric] hospital's lead psychologist Jonathan Scholtz concluded that Pistorius has been severely traumatised by the events of 14 February 2013. (The Times)

14) The defence produced a detailed timeline that it said demonstrated the screams heard by neighbours were not from Steenkamp but a desperate Pistorius, horrified and crying for help. (Guardian)

In many cases, including the extracts quoted above, the media are reporting on the statements of individuals involved in the case. It could be claimed therefore that they do not necessarily support the representations constructed by the words of these individuals. However, the journalists choose whose words to report on, and whether to quote them directly or to paraphrase what was said, as is the case in the majority of instances, thereby potentially inserting their own stance.

Race and nationality are not thematised as such in this sub-corpus, but the representations fit the pattern of crimes by white people being seen as individual crimes and as aberrations caused by individual problems (e.g. mental illness, problems in childhood etc). Although the hegemonic masculinity is 'sacrificed' through emotional and gendered representations, the hegemonic moral order is sustained: there is nothing wrong with the white section of the South African society and this is just a single 
instance, an unfortunate murder committed by a white, vulnerable and anxious man afraid of (black) crime in his country.

Table 5: Collocations of Pistorius in SA2

\begin{tabular}{|l|l|l|}
\hline Semantic Domain & Collocations & $\begin{array}{l}\text { Total } \\
\text { freq. }\end{array}$ \\
\hline Naming of Pistorius & $\begin{array}{l}\text { Oscar (1658), murder (224), accuse (100), } \\
\text { paralympian (81), boyfriend (25), paralympic } \\
\text { (24), Olympian (17), murder-accused (14), } \\
\text { shooter (4), gunman (4), superstar (3), sprinter } \\
\text { (3), liar (3) }\end{array}$ & 1836 \\
\hline Court procedure & $\begin{array}{l}\text { trial (385), murder (224), accuse (100), dock } \\
\text { (22), psychiatric (13), assertion (10), preside (7), } \\
\text { indict (4), 30-day (observation) (4), defamation } \\
\text { (4), inconsistent (testimony) (4), trials (4), } \\
\text { improbability (4), disprove (4), session (4), } \\
\text { negotiate (4), substantiate (3), violate (bail) (3), } \\
\text { re-enact (3), usher (3), cops (3), unprecedented } \\
\text { (3), contention (3) }\end{array}$ & \\
\hline Social relations & $\begin{array}{l}\text { uncle (69), dad (11), clan (8), mom (6), ex- } \\
\text { girlfriend (5) }\end{array}$ & 99 \\
\hline $\begin{array}{l}\text { Bodily and mental states } \\
\text { and actions }\end{array}$ & $\begin{array}{l}\text { retch (14), mourn (10), tearful (10), trigger- } \\
\text { happy (7), scuffle (5), bleed (4), suicidal (4), } \\
\text { weep (4), emotionally (4), shocking (3), worried } \\
\text { (3), spat (3) }\end{array}$ & 71 \\
\hline pale (6), puzzling (4), chilling (4), inconsolable \\
(4), sporting (4)
\end{tabular}

A rather different picture emerges from the SA corpus. Apart from his first name, the most frequent group of collocates in this sub-corpus which refer to Pistorius are terms referencing his status as a person accused of murder (356, in Italics, in Table 5 above). The two most frequent of these lemmas have been duplicated in the semantic domain of terms relating to the trial and court proceedings because, on the surface of it, murder and 
accuse $(d)$ are both legal terms. However, they are doing double duty in this data in that their chief role is acting as identifiers for Pistorius. His name is frequently modified by the phrase, as in murder accused Oscar Pistorius (64) and Pistorius has murder as a relatively strong collocate with an MI score of 6.27. He is even more frequently referred to without the use of his name, but simply in terms of his role in the trial: as murder accused (31) or the accused (216), which reduces the MI score for this lemma as a collocate with his name because it is also frequently used alone. Other elements of his identity are combined with murder accused in the following patterns:

athlete Oscar Pistorius (2)

Olympian Oscar Pistorius

Olympic athlete Oscar Pistorius

paralympian/ic (5) murder accused Oscar Pistorius (64)

Paralympian Oscar Pistorius (9)

Paralympian

Paralympian sporting icon

Paralympic athlete Oscar Pistorius (2)

His identity as murder accused most often stands alone with his name, but is sometimes represented in combination with his status as a Para/Olympic athlete: he is identified as a sporting icon once and as an athlete three times, as an Olympian twice, and as a Paralympian 18 times. In general, relatively few collocates of his name refer to his 
identity as a sportsman and Olympian (132), as opposed to those related to murder (356), as seen in Table 5.

The tendency seen here to emphasize his participation in the Paralympics rather than the Olympics is repeated in the SA2 corpus as a whole, with the following terms referring to Pistorius: Olympic (43), Olympian (40), Paralympic (20), Paralympian (214). The shift in representation from the early corpus, where his participation in the able-bodied Olympics was foregrounded over his performance in the Paralympics, works together with other collocates such as orthopaedic and double amputee to emphasize his status as a disabled man, especially in comparison with UK2, where his disability is not foregrounded at all. In fact the phrase double amputee is used to refer to Pistorius an additional 53 times, without his name accompanying it. The emphasis on this aspect of his identity is important as his defence was underpinned by the claim that he had felt especially vulnerable to intruders as a result of his disability, explaining why he had made no warning shot, nor called out, before firing four times through the toilet door.

The collocate kneel refers to the curious pantomime which formed a substantial segment of the trial, and the reporting on it, in which his disability was made tangible. It dealt with the question of whether Pistorius was 'on his stumps' when he shot Reeva and when he later hit the door with a cricket bat. During the trial, a toilet cubicle identical to that in Pistorius's home was constructed in the courtroom, and the police's forensic science expert was instructed to kneel in the spot equivalent to where Pistorius had been, to demonstrate Pistorius's actions at the time of the murder. Journalists reporting on the trial also describe re-enacting this, kneeling at the scene of the murder to recreate Pistorius's point of view. By making his disability salient and emphasizing his resulting 
vulnerability as a disabled person in "crime-ridden" South Africa, this representation supplies a frame within which local readers may interpret what happened, and assists in making his crime contextually comprehensible.

That is not to say, however, that the representations are necessarily sympathetic to Pistorius or his actions: they are not. Although the media are reporting on the events occurring in court, and could be seen as being limited to a particular narrative as a result, the ways in which proceedings are described are far from neutral. Two themes emerge in the representation of Pistorius which serve to undermine his defence as a vulnerable person and to convey negative expressive value: the description of contexts in which Pistorius is claimed to have been violent, other than the murder of Reeva Steenkamp itself, and the characterization of his emotional behaviour in court.

The data include reportage of other examples of violent behaviour in Pistorius's past, which include irresponsible behaviour with firearms. The cumulative picture is one of a man who is quick to anger, and who overreacts. The nouns spat (5) and scuffle (9) are both statistically significant collocates with Pistorius, and refer to angry outbursts, sometimes physically violent, on the part of the athlete, such as Extracts 14 - 17:

14) The claimed spat resulted in Pistorius allegedly threatening to break Van der Burgh's legs. (The Times)

15) Batchelor is expected to testify about an altercation between him and Pistorius during which the athlete threatened to "break his legs". (Sunday Times)

16) A man who was in the club... saw a scuffle near the VIP section. "I said to my friend 'check over there, there's a fight'," the man said. (The Star) 
17) The State was expected to serve Pistorius with two extra charges today - those of recklessly discharging a weapon in a public place, which may assist in the State's attempts to portray him as trigger-happy. The other charge relates to two incidents ... in which he allegedly fired his gun out of the sunroof of a car, and the second for shooting in a popular Joburg restaurant. (The Star)

While choosing to report on these events is not entirely unexpected, given that they were introduced in the trial, the choice of words used to describe Pistorius's behaviour is not neutral. With reference to the examples above, the writers of (14) and (15) use the lemma THREATEN, as opposed to a more neutral reporting verb. Pistorius is described as being trigger-happy in (17), suggesting an irresponsible attitude, when he could simply be represented as a registered gun owner, which gives the impression of a reasonable, law-abiding adult. As always, it is lexical choices, some subtle, some not so subtle, which build a cumulative image in the mind of the reader, which in turn constructs the identity of the person represented, in this case Pistorius.

As in UK2, the 57 tokens of emotional expression which collocate with his name paint a composite picture of a distressed Pistorius, but unlike the UK data, here it seems these terms are not to be taken at face value. While tearful, mourn, inconsolable and weep index sadness, and retch a more visceral reaction to the details of the crime, the way these behaviours are framed introduces the possibility that they are tactics, disingenuous strategies to gain sympathy, and the reporters are not necessarily buying it. In addition, in contrast with UK2 where Pistorius is most frequently described as weeping, a quiet 
emotional display, in SA2 the use of verbs like howling and wailed suggests ostentatious emotional display and contributes to a somewhat unsympathetic tone:

18) Tears flow, sister Aimee, uncle Arnold and his wife Lois ... they all cry. Pistorius is inconsolable, the court adjourns and he continues howling loudly outside in the corridor. (The Star)

19) He broke down and wailed bitterly. His sister Aimee and brother Carl ran over to comfort him. But Oscar Pistorius was inconsolable, covering his face with his hands and letting out piercing cries. In the public gallery, Reeva Steenkamp's mother June was unmoved. She looked straight at him. No emotion, just a blank stare.... Pistorius's wailing continued as his siblings and legal team huddled around him. Then they walked out with him as h continued to cry inconsolably outside Court GD. (The Star)

The unsympathetic reporting of his emotions serves to create distance between the readers and the man - we are encouraged to view him coldly, without empathy, like Reeva Steenkamp's mother. The following extract from another article in The Star is probably the most extreme in its scornful attitude to Pistorius's emotional behaviour in court.

20) there was scarcely an attempt at atonement on the part of the Paralympian.

What meagre effort there was at pleading forgiveness was soon overshadowed by what Reeva's brother characterised as Pistorius' "grotesque pantomime of courtroom histrionics... The tears that flowed seemingly on demand, the strings of snot repugnantly dripping from his nose (clearly another ploy at garnering sympathy what, could none of his supporters offer him a tissue?), the OTT retching into the 
infamous green bucket ${ }^{2}$ and the garbled (annoying) sobbing voice." It was indeed a portrayal worthy of an Oscar for Best Actor in a Courtroom Drama miniseries. The fleeting but unmistakable smirk that crossed his face when Judge Thokozile Mapisa cleared him of actual murder

By minimising Pistorius's remorse (underlined) and mocking his emotional display (in Italics) the text calls into question the sincerity of his emotion, pointing out that his name is associated with acting. The extended quotation from Reeva's brother privileges his view, and reports uncritically his claim that Pistorius's behaviour is put on, an intentional ploy to win sympathy, thus suggesting that Steenkamp's interpretation of events is true.

Representing Pistorius as both quick to (violent) anger and capable of manipulation not only provides the reader with an unsympathetic frame within which to interpret the events surrounding Reeva Steenkamp's death. It also constructs his identity, particularly his personality, in negative ways.

A further aspect of the display of emotion is strongly gendered. During the trial neighbours testified to hearing screams and gunshots coming from Pistorius's house during the night of the murder. One element of the defence's case was to claim that, when upset, Pistorius "screams like a girl". The screams were described variously as bloodcurdling (frequency 21, MI 12), petrified (13, MI 11.9), fearful, distressed and terrified (all MI>9). The Sunday Times describes attempts by Pistorius's defence team to attribute these screams to Pistorius ${ }^{3}$, identifying the contradiction with the masculine

\footnotetext{
2 This refers to the green bucket into which Pistorius would retch (the strongest lemma collocate of emotion with a frequency of 14 and an MI score of 5.7) during the trial.

${ }^{3}$ If the screams were identified as belonging to a woman, it could be argued that Pistorius knew that Ms Steenkamp was in the toilet cubicle, before he shot through the door.
} 
image he had cultivated up to that point. The journalist, in describing the disbelieving responses of the people in the court, encourages the reader to find the defence's claims equally implausible.

21) Yes, advocate Barry Roux told some witnesses, ... you did hear screams. And yes, to you they sounded like that of a woman.... Those screams belonged to my client: Pistorius. After the laughter and astonishment settled in court, Roux drove home his point. He would be able to call expert witnesses who could testify that Pistorius, when anxious, sounds like a woman when he screams. He said Pistorius's voice, at a certain pitch, could fool anyone into thinking it was a female clearing her lungs. This contention surprised a lot of people. An athlete who had built his brand on his masculinity - he was voted South Africa's sexiest man; he drove fast cars — was willing to ditch this macho image for his freedom.

The Sunday Times locates this celebrity case within the national prevalence of domestic violence, claiming that while this kind of crime is too common to be of national interest in itself, Pistorius's identity as a celebrity made it newsworthy and "elevated Oscar Pistorius above every other man who killed his girlfriend on that Valentine's Day, and every other day before and after". But they add that it also served to elide the broader issues of gender relations in South Africa. The Sunday Times links gender and courage to heroic qualities in commenting that Pistorius displayed "no Olympian heroism as Oscar fails to man up".

There is intertextual reference to another prominent case with the name Shrien (45 in total) showing up as a strong collocate with Pistorius (9). This refers to UK businessman 
Shrien Dewani, who was accused of orchestrating the murder of his wife, Anni, while on honeymoon in Cape Town, and who was awaiting trial at the time. By linking the Pistorius and Dewani cases, the SA media emphasize the often male-on-female nature of domestic violence, and downplay the nationality and race of either accused, showing that partner-abuse cuts across both facets of identity. Indeed, Pistorius's race is only mentioned in the Sunday Times, twice, in an interview with a former fellow student of the presiding judge. The interviewee comments on the change in roles evident in the case, saying the following:

22) Here is a black woman today who has the fate of a white boy in her hands

It is surely significant that she refers to the judge as a woman, but to the accused as a boy, a marked usage for an adult that was historically used by some white people in South Africa to exert dominance over black males.

Also infrequent is the mention of nationality with just two references including Pistorius's nationality in this sub-corpus. One incorporates his nationality in a list of contrasting murderer:hero identities:

23) An encrypted iPhone recovered from the bloody bathroom of murder accused and South African Olympic hero Oscar Pistorius is believed to be crucial

Given that Pistorius was not referred to as a hero when winning gold medals in the Paralympics, it is telling that although he is frequently referred to as a hero in this subcorpus, the majority of these references are negative or in the past tense. Fallen is the most frequent collocate to the left of hero, and the one with the highest MI, at 10.3. As Susan de Groot, writing in the Sunday Times, says: 
24) We may never know exactly what happened in Silver Woods Estate on Valentine's Day last year, only that one young life was lost and another irrevocably ruined. Oscar may not be a villain, but he is certainly no longer a hero.

In sum, in this sub-corpus Pistorius's identity as a person who killed another person is most dominant, with the strong and aggressive collocates murder accused, trigger-happy, gunman and shooter. In this context his disability is foregrounded (double amputee) as a possible defence. The fact that he is/was a celebrity and well off financially probably accounts for much of the national focus on the case, as opposed to any of the other cases of domestic abuse in South Africa in 2013. As a white man in South Africa, he might have expected to extract some status from the residual stratification of Apartheid, and indeed his defence is based on what is assumed to be a shared belief in the vulnerability of white people, particularly disabled people, to black criminals, but his race is seldom overtly mentioned in the corpus. On the contrary, the exceptions are the comments on the reversal of power relations between a black woman judge and a white male accused. Here, as in the intertextual link to the Shrien Dewani case, it is gender identity, and entrenched gender roles, which are shown to be constant in domestic violence, rather than race or nationality, which are backgrounded. In fact, his masculine identity which would typically infuse him with more power is sacrificed in an attempt to reduce the blame placed on him when he is claimed to "scream like a girl". His emotional state during the trial, including his high-pitched wails, is foregrounded but is described with considerable negative prosody which has the effect of casting doubt on his sincerity. In conclusion, 
while he is still frequently referred to as a sportsman in the later SA corpus, and a successful one, it is as a 'fallen hero' that he is judged.

\section{Discussion and conclusions}

There are tantalising differences and similarities across the corpora - both in terms of time period and country. In this final section we review how Pistorius is represented in terms of race, gender, nationality and his identity as both a sportsman and a murderer, and discuss the impact of the cultural and socio-political context on representational choices and the kind of intersections that are foregrounded or backgrounded.

Identity terms reflecting Pistorius as an athlete outnumber those for him as a murderer in $\mathrm{UK} 2$ but this is reversed in SA2, where there is a great emphasis on his status as a 'murder accused'. How these elements are combined with other facets of his identity, and which aspects are ignored, suggests the techniques used by the media to straddle these apparently irreconcilable personae. It is significant that both media contexts refer to him overwhelmingly by name, creating a focus on an individual, as opposed to positioning him as a member of an identity group, and certain identities are all but ignored.

Neither his race nor his nationality are foregrounded in the later corpora. His nationality is largely ignored, with Team SA seemingly reluctant to claim their superstar. The fact of his race in stratified South Africa is invoked obliquely via his defence as an amputee, vulnerable to attack by an intruder who is presumed to be black, an ideological assumption which all local readers would be familiar with. The arrangement of roles in the case itself turned historical relations of power on their head, with a black woman 
deciding the fate of a white man, but this was seldom mentioned. Given the relationship between the events of the case and existing ideologies of racialised crime, not only in South Africa but internationally, it is perhaps not surprising that race was largely ignored in both corpora, because to foreground this would disrupt the dominant narrative associating violent crime with black males, rather than white males. This might also explain the UK press eliding his status as a South African.

His sex is located as part of a trend of violence by men against their domestic partners, with intertextual references to the Shrien Dewani case in SA2. But gender is raised in more complex ways in both later corpora in the treatment of Pistorius's emotional displays. In UK2, his alignment with hegemonic masculinity is seen to be sacrificed via emotional leakage to garner sympathy and portray innocence, while in SA2 the screams heard by neighbours and purported to be his also undermine his masculinity, while supporting his defence. The emotional outbursts during the trial are sometimes represented in the SA media as manipulative attempts to gain sympathy, rather than being indicative of innocence or worthy of sympathy themselves.

Indeed his physical strength as a man and as an athlete is underplayed in the SA2 corpus, with frequent references to his disability which was used in his defence but his Olympian status seldom mentioned. Do South Africans feel cheated for idealising him in SA1? It is possible that his gold-medallist status is largely ignored and his emotional outbursts are so harshly judged in an attempt to obscure the mismatch between who South Africans thought Pistorius was and who he has been revealed to be: a murderer, not a hero. In not taking responsibility for how he used to be seen, SA media also construct Reeva's murder as an individual crime, and no reflection on South Africans/males/whites. 
The ways in which choices in representation support hegemonic identities, especially in the case of an intersectionally-rich and changing identity such as Pistorius's, reflect the differences in ideological context and media practice in the UK and SA. In UK2, the emphases and elisions serve to focus on his existing physical and new emotional and mental vulnerabilities, and cast him as a victim, not a murderer, while playing down those elements of his personality which might give him structural power: his masculinity and, in the South African context, his race, thereby leaving undisrupted the dominant association of whiteness with victimhood in crime. In contrast, in SA2, his identity as a murderer is foregrounded, with an emphasis on previous examples of aggression, and the case is located in the currently prominent frame of male-on-female (domestic) violence in the country. But his status as a disabled person, also foregrounded, works against this and provides mitigation by increasing his vulnerability in the same ideological arrangement of white victimhood as seen in UK2.

The mediatisation of very diverse intersectional identities like Pistorius's, which also changes over time, is a complex process in which linguistic choices are moulded by and similarly reflect dominant views of identity and identities. It is in the context of hegemonic beliefs about crime and race, and emotion and masculinity, that we are able to see Pistorius constructed, and understand the media creation that is him. Aspects of his identity which are disruptive to dominant views are simply elided. Others are manipulated or employed in combination to support existing beliefs. Pistorius's early representation in both contexts is one of exceptionalism: a hero against all odds. Later the two corpora reflect different characters: in the UK a white victim, hardly a man; in South Africa a disabled murderer, two identities which work in opposition to each other and 
link in complex ways to categories like race and gender. Pistorius is no longer a hero in either context. It is no great surprise that the mainstream media in the UK and in SA are colluding in the process of maintaining the status quo: it is the world their readers understand, and the context in which they can make sense of this most extreme crime.

The choice of Oscar Pistorius as a case study of the representation of intersectionality in the media is a fortuitous one. Seldom is one presented with such contrasts in identity in one individual in a relatively short space of time. The fact that he was in the media spotlight in both countries in both time periods provided us with the perfect opportunity to unravel patterns of intersectionality in representational choices reflecting his dramatic change in status. The benefits of such a diachronic collocation analysis in two contexts are substantial, especially when focussing on one person. Collocations with his name extracted from the four corpora we assembled enabled us to compare which aspects of identity are foregrounded and elided across time, and in different contexts. These throw into sharp relief elements such as gender, nationality and race, but also reveal how media constructions are located within, and contribute to, dominant ideological systems of meaning in different national, social and cultural contexts.

\section{References}

Aull, L., Brown, D. W., 2013. Fighting words: a corpus analysis of gender representations in sports reportage. Corpora. 8, 27-52. https://doi.org/10.3366/cor.2013.0033.

Baker, P., Gabrielatos, C., McEnery, T., 2013. Discourse analysis and media attitudes. Cambridge University Press, Cambridge.

Bruce, T., Hovden, J., Markula, P., 2010. Sportswomen at the Olympics: A global comparison of newspaper coverage. Sense, Rotterdam. 
Bucholtz, M., 2011. 2011. White kids: language, race and styles of youth identity. Cambridge University Press, Cambridge.

Caple, H., 2013. Competing for coverage: exploring emerging discourses on female athletes in the Australian print media. English Text Construction. 6(2), 271-94. https://doi.org/10.1075/etc.6.2.03cap

Chilton, P., 2011. Still something missing in CDA. Discourse Studies13(6), 769-781. https://doi.org/10.1177/1461445611421360a

Crenshaw, K., 1991. Mapping the margins: intersectionality, identity politics, and violence against women of color. Stanford Law Review. 43, 1241-99. https://doi.org/10.2307/1229039

Dixon, T. L., Maddox, K. B., 2005. Skin tone, crime news, and social reality judgments: Priming the stereotype of the dark and dangerous black criminal. Journal of Applied Social Psychology. 35(8), 1555-1570. https://doi.org/10.1111/j.1559$\underline{1816.2005 . t b 02184 . x}$

Dixon, T. L., 2017. Good guys are still always in white? Positive change and continued misrepresentation of race and crime on local television news. Communication Research. 44 (6), 775-792. https://doi.org/10.1177/0093650215579223

Eckert, P., 1989. Eckert, Penelope. 1989a. Jocks and burnouts: social categories and identity in the high school. Teachers College Press, New York.

Eckert, P., 2016. Variation, meaning and social change, in: Coupland, N. (Ed.), Sociolinguistics. Theoretical debate. Cambridge University Press, Cambridge, pp. 68-85.

Farr, K. A., 2001. Women on death row: media representations of female evil, in: Eber, D., Neal, G. (Eds.). Memory and representation: constructed truths and competing realities. Bowling Green State University Press, Bowling Green, pp. 73-86.

Gee, P. J. 2014. An introduction to discourse analysis: theory and method. Fourth edition. London/New York, Routledge.

Gilchrist, K., 2010. "Newsworthy” Victims? Feminist Media Studies. 10(4), 373-390. https://doi.org/10.1080/14680777.2010.514110.

Gilliam, F. D., Iyengar, S., Simon, A., Wright, O., 1996. Crime in black and white: The violent, scary world of local news. Harvard International Journal of Press/Politics. 1, 6-23. https://doi.org/10.1177/1081180X96001003003. 
Harper, C., A., Hougue, T. E., 2015. The emotional representation of sexual crime in the national British press. Journal of Language and Social Psychology. 34(1), 3-24. https://doi.org/10.1177/0261927X14544474.

Henry, F., Tator, C., 2006. The colour of democracy: racism in Canadian society, Nelson, Toronto.

Hunt, S., 2017. Representations of gender and agency in the Harry Potter series, in: Baker, P., McEnery, T., (Eds.). Corpora and discourse studies: integrating discourse and corpora. Palgrave Macmillan, London, pp. 266-284.

Jaffe, A., 2011. Sociolinguistic diversity in mainstream media: Authenticity, authority and processes of mediation and mediatization. Journal of Language and Politics. 10(4), 95-119.

Jaworska, S. 2016. Using a Corpus-Assisted Discourse Studies (CADS) Approach to Investigate Constructions of Identities in Media Reporting Surrounding Mega Sports Events: The Case of the London Olympics 2012, in: Lamond, I., Platt, L. (Eds.), Critical events studies: approaches to research. Palgrave Macmillan, London, pp. 149-74. https://doi.org/10.1057/978-1-137-52386-0_8

Jaworska, S., Krishnamurthy, R., 2012. On the F-word: a corpus-based analysis of the media representation of feminism in British and German press discourse, 19902009. Discourse and Society. 23, 401-31. https://doi.org/10.1177/0957926512441113.

Jaworska, S., Hunt, S., 2017. Intersections and differentiations: a corpus-assisted discourse study of gender representations in the British press before, during and after the London Olympics 2012. Gender and Language. 11(3), 336-364. 10.1558/genl.28858

Jewkes, Y., 2004. Media \& Crime. Sage, London.

Johnson, S., Ensslin, A., 2007. Language in the media: Representations, identities, ideologies. Bloomsbury, London.

Kiesling, S., 2006. Hegemonic identity-making in narrative, in: De Fina, A., Schiffrin, D., Bamberg, M., (Eds.). Discourse and identity. Cambridge University Press, Cambridge, pp. 261-287.

Kilgarriff, A., Rychlý, P., Smrz, P., Tugwell, D., 2004. The Sketch Engine, in: Proceedings of EURALEX 200, Lorient, France, pp. 105-116.

Kitzinger, J., 2009. Rape in the media, in: Horvath, M., Brown, J. (Eds.). Rape: challenging contemporary thinking. Willan, Cullompton, pp. 74-98. 
Leuschner, T., Jaworska, S., 2018. Introduction: Anglo-German discourse crossings and contrasts. Pragmatics and Society. 9(1), 2-7. https://doi.org/10.1075/ps.16029.jaw

Levon, E., 2014. Categories, stereotypes and the linguistic perception of sexuality. Language in Society. 43(5), 539-66. https://doi.org/10.1017/S0047404514000554

Levon, E., 2015. Integrating Intersectionality in language, gender, and sexuality research. Language and Linguistics Compass. 9(7), 295-308. https://doi.org/10.1111/lnc3.12147

Machin, D., Mayr, A., 2013. Personalising crime and crime-fighting in factual television: an analysis of social actors and transitivity in language and images. Critical Discourse Studies. 10(4), 356-372. https://doi.org/10.1080/17405904.2013.813771.

Messner, M., Duncan, M., Jenson, K., 1993. Separating the men from the girls: the gendered language of televised sports. Gender and Society. 7, 121-37. https://doi.org/10.1177/089124393007001007.

Milani, T., 2015. Language and masculinities: performances, intersections, dislocations. Routledge, New York.

Statham, S., 2016. Redefining trial by media: towards a critical-forensic linguistic interface. Benjamins, Philiadelphia.

Surette, R., 2009. The entertainment media and the social construction of crime and justice, in: Jewkes, Y. (Ed.), Crime and Media, volume 2: media representations of crime and criminal justice. Sage, London, pp. 239-268.

Tabbert, U., 2013. Language and crime. Constructing offenders and victims in newspaper reports. Palgrave Macmillan, London.

Umraw, A. 2018 Are Attacks on white farmers really racially motivated? Here are the facts 16/23 March 2018. https://www.huffingtonpost.co.za/2018/03/15/southafricas-white-genocide-these-are-the-facts_a_23386613/

Webster, C., 2017. Race, religion, victims and crime, in: Davies, P., Francis, P., Greer, C. (Eds.). Victims, crime and society. Sage, London, pp. 207-228.

Zimmerman, D. H., Wieder, D. L., 1970. Ethnomethodology and the problem of order: comment on Denzin, in Douglas, J. D. (Ed.) Understanding everyday life: toward the reconstruction of sociological knowledge. Chicago, Aldine Publishing, pp. 285298. 